\title{
Relationship between Working Capital Management and the Performance of Firm in Different Business Cycles
}

\author{
Maryam Pakdel ${ }^{1}$, Majid Ashrafi ${ }^{1 *}$ \\ ${ }^{1}$ Department of Accounting, Aliabad Katoul Branch, Islamic Azad University, Aliabad Katoul, IRAN
}

*Corresponding Author: Mjd_Ashrafi@yahoo.com

Citation: Pakdel, M. and Ashrafi, M. (2019). Relationship between Working Capital Management and the Performance of Firm in Different Business Cycles. Dutch Journal of Finance and Management, 3(1), em0057. https://doi.org/10.29333/djfm/5874

Published: May 7, 2019

\begin{abstract}
Working capital management is one of the issues that plays an important role in the management structure of an organization and as one of the main force moving forward organizations, it is important to obtain huge economic benefits. This study focused on the relationship between working capital management and the performance of firm in different business cycles. A sample consist of 80 companies listed in Tehran Stock Exchange from 2002 to 2013 have been selected. In this study, the cash conversion cycle is considered as a measure of working capital management, which consists of days account receivable, days inventory and days account payable. Hypotheses of this study were analyzed using panel method data and the results show that there is a significant negative relationship among the management of working capital and firm performance. Among the components of cash conversion cycle, only day's account receivable has negative and significant relationship with firm performance. The results also show that the various business cycles do not modify the relationship between working capital management and the performance of companies.
\end{abstract}

Keywords: working capital management, days account receivable, days inventory, days account payable, performance

\section{INTRODUCTION}

Working capital management is a key component of corporate finance management because it directly affects profitability (Gill et al., 2010). Working capital is the firm's investment in short-term assets such as cash, shortterm securities, accounts receivable and inventory, and net working capital is defined as current assets minus current liabilities (Mohammadi, 2009). Nowadays, working capital management that is the management of resources and current expenditures to maximize shareholder wealth, as part of the task of financial management is important (Cot \& Latham 1999). For amazon.com companies in the mid-2000s, working capital management is the key to healthy cash flow and they believe that companies with poor working capital management strategy gradually lose their flexibility and competitive advantage (BahaarMoghadam et al., 2012). Business cycles are fluctuations in total production, income and national employment, which usually lasts from 2 to 10 years and its main indicator, is development or recession in the most sectors of the economy. The economic boom period, refers to the periods that the real GDP started to grow and in the recession period it refers to the periods that it is accompanied by a reduction of real GDP and intercourse with it due to a drop in sales, firms make decisions on reducing the number of workers, buy less raw material and stop development projects in order to reduce spending their expenditures. According to the literature, studies about the relationship between working capital management and the performance of companies in the Tehran Stock Exchange has been done, however, no research regarding the relationship between working capital management on the performance of companies in different business 
cycles have been performed. This study could be a step for theoretical studies about an important part of financial management i.e. the company's working capital management. According to spread of the culture of working capital management, it may solve some companies problems so this study scientifically and academically is necessary.

\section{Literature Review and Development of Hypotheses}

Cash conversion cycle that is a comprehensive and efficient tool for managing the working capital is widely used in studies. Cash conversion cycle is elapsed time between a company's funding for supplying raw materials and the collection of sales of the finish goods; that in this study we consider it as a measure of working capital management. The purpose of efficient working capital management practices is shorten the cash conversion cycle in order to optimize the levels that are perfectly suited to the requirements of a company. Short-term cash conversion cycle as fast collection of receivables and payment obligations to producers is associated with firm performance. In their study, Karadagli (2012), Yeboah and Kwakuagyei (2012), Aregbeyen (2011), Gill et al (2010), Lazaridis and Tryfonidis (2006), Wang (2002) and Lotfi et al (2012) concluded that there is a negative relationship between the cash conversion cycle and profitability. Cash conversion cycle has three components: days account payable, days account receivable, days inventory. A company by independent optimizing each of these three components minimizes the cash conversion cycle, for example, accounts payable is considered as flexible and affordable source of firm's funding. Delays in payments to firm's producers increase payable accounts payable which in turn significantly reduce cash conversion cycle and provides more efficient working capital. In their research, Samadi Largany and Aymani (2013) concluded that there is a positive relationship between the payment obligations period and profitability. Surplus inventories and longer cash conversion cycle of accounts receivable are leading to an increase in the cash conversion cycle. As a result, companies with low inventory that collect their receivables quickly, have shorter cash conversion cycle and are more efficient, which ultimately have a positive impact on performance.

Given the above, the following hypotheses are considered:

$\mathrm{H}_{1}$. Working capital management has a negative relationship with the firm performance.

$\mathrm{H}_{11}$. There is a negative relationship between the days account receivable and the firm performance.

$\mathrm{H}_{12}$. There is a positive relationship between the days account payable and the firm performance.

$\mathrm{H}_{13}$. There is a negative relationship between the day's inventory and the firm performance.

Changes in the macroeconomic will effect on investments and the way of company's providing financial capital. Economic recessions and crises attach great importance to liquidity and focus on working capital Conditions. Korajczyk and Levy (2003) suggest that companies that are in financial distress, compared with companies that are not financial distress reacts differently to macroeconomic uncertainty. Such periods indicate that longer periods of time are more likely to collect accounts receivable and inventory due to stop sales. As a result, companies must have additional requirements for working capital. Due to the increasing challenges of undesirable economic terms we assume that working capital management should be seen as more important than the performance during economic recessions. Furthermore, due to the improvement in fixed capital investments and demand during the economic boom has been assumed that the relationship between working capital and profitability in improved economic terms would be less significant (Graham et al., 2014). In an empirical research, Einarsson and Marquis (2001) found that levels of trust and Citation of corporates to funding by bank to meet the needs of working capital in the United States are counter-cyclical and increase with the weakening of the economic situation. Braun and Larrian (2005) also concluded that working capital requirements and conditions are considered as the main cause of business dependence on external financial funding. They suggest that companies that highly depended on foreign financial funding have been most affected by the economic crisis and should be more cautious in terms of the decline and fall of the economy, including the supply of reserves in the working capital during crisis, Chiou et al (2006) pointed to the importance of the economic situation and assess the determinants of working capital to the indexes of trade and found a positive relationship between indexes of trade and working capital requirements.

$\mathrm{H}_{2}$. Various business cycles moderate the relationship between working capital management and firms' performance. (Intensity of negative relationship of working capital management and the company's performance in the Tehran Stock Exchange increases during the economic recession and the intensity of negative relationship between working capital management and the company's performance in the Tehran Stock Exchange decreases during the boom in the economy.

$\mathrm{H}_{21}$. The intensity of negative correlation between the days accounts receivable and firms' performance increases during the economic downturn.

$\mathrm{H}_{22}$. The intensity of negative correlation between the days accounts receivable and firms' performance decreases during the economic boom.

$\mathrm{H}_{23}$. The intensity of positive correlation between the days account payable and firms' performance increases during the economic downturn. 
Dutch Journal of Finance and Management, 3(1), em0057

Table 1. Test Engine Specifications

\begin{tabular}{|c|c|c|c|c|}
\hline & Variable & Variable name & Symbol & Calculation Method \\
\hline \multirow{5}{*}{1} & \multirow{5}{*}{$\begin{array}{l}\text { Independent } \\
\text { Variable }\end{array}$} & Working capital management & CCC & (Days Account Receivable + Days Inventory) - (Days Account Payable) \\
\hline & & \multirow{2}{*}{ Days Account Receivable } & \multirow{2}{*}{ DAR } & $($ Accounts Receivables $) * 365$ \\
\hline & & & & Sales \\
\hline & & Days Account Payable & DAP & $\left(\frac{\text { Accounts Payables }}{\text { Cost of oods Sold }}\right) * 365$ \\
\hline & & Days Inventory & DI & $\left(\frac{\text { Inventory }}{\text { Coct }}\right) * 365$ \\
\hline \multirow{2}{*}{2} & Dependent & \multirow{2}{*}{ Operation } & \multirow{2}{*}{ Q } & Market value of Equity + book value debt \\
\hline & Variable & & & book value assets \\
\hline \multirow{2}{*}{3} & \multirow{2}{*}{$\begin{array}{l}\text { Moderating } \\
\text { Variable }\end{array}$} & recession dummy variable & $\mathrm{D}_{1}$ & Variable 4 Years of the Lowest GDP Growth \\
\hline & & boom dummy variable & $\mathrm{D}_{2}$ & Variable 4 Years Most of the Highest GDP Growth \\
\hline \multirow{4}{*}{4} & \multirow{4}{*}{$\begin{array}{l}\text { Control } \\
\text { Variable }\end{array}$} & Firm Size & SIZE & Natural Logarithm of Sales \\
\hline & & \multirow{2}{*}{ Leverage } & \multirow{2}{*}{ LEV } & Total Debt \\
\hline & & & & $\frac{\text { Total Assets }}{\text { book Value Of Intangibles Assets }}$ \\
\hline & & GROWTH Opportunities & GROWTH & $\left(\frac{\text { Total Assets }}{2}\right.$ \\
\hline
\end{tabular}

$\mathrm{H}_{24}$. The intensity of positive correlation between the days account payable and firms' performance decreases during the economic boom.

$\mathrm{H}_{25}$. The intensity of negative correlation between the day's inventory and firms' performance increases during the economic downturn.

$\mathrm{H}_{26}$. The intensity of negative correlation between the day's inventory and firms' performance decreases during the economic boom.

\section{METHODOLOGY}

From an objective viewpoint, this research is practical and from the viewpoint of nature and method, it is causal. Data collection method is through library. As well as the main reports and financial statements of under evaluation companies collected through tadbir pardaz software and Codal network. Spatial and temporal scope of the study is the Tehran Stock Exchange In a twelve-year period from 2002 to 2013. The study population consisted of listed companies on the stock exchange. And considered restrictions include the following:

1- Financial firms (banks and institutions financial, investment firms, financial intermediaries).

2- Companies that do not have required and extractable information since 2002 to 2013.

3- Companies that their financial year does not end on 29 March

4- Companies that changed their financial year between years of 2002 to 2013.

5- Companies that have a three-month period to stop the transaction in studied period.

After applying the above restrictions, a total of 80 companies as sample were selected randomly.

\section{Statistical Models and Variables}

The statistical model is as follows:

$$
\begin{aligned}
& \text { Qit }=\beta 0+\beta 1 \text { CCCit }+\beta 2 \text { SIZEit }+\beta 3 \text { LEVit }+\beta 4 \text { GROWTHit }+\varepsilon i t \\
& \text { Qit }=\beta 0+\beta 1 \text { DARit }+\beta 2 \text { SIZEit }+\beta 3 \text { LEVit }+\beta 4 \text { GROWTHit }+\varepsilon i t \\
& \text { Qit }=\beta 0+\beta 1 \text { CCCit }+\beta 2 \text { SIZEit }+\beta 3 \text { LEVit }+\beta \text { GGROWTHit }+\varepsilon i t \\
& \text { Qit }=\beta 0+\beta 1 \text { DARit }+\beta 2 \text { SIZEit }+\beta 3 \text { LEVit }+\beta 4 \text { GROWTHit }+\varepsilon i t \\
& \mathrm{Qit}=\beta 0+\beta 1 \text { CCCit }+\beta 2 \mathrm{D} 1+\beta 3 \mathrm{D} 2+\beta 4(\mathrm{D} 1 \times \mathrm{CCCit})+\beta 5(\mathrm{D} 2 \times \mathrm{CCCit})+\beta 6 \text { SIZEit }+\beta 7 \mathrm{LEVit} \\
& +\beta 8 \text { GROWTHit }+\varepsilon \text { it } \\
& \mathrm{Qit}=\beta 0+\beta 1 \mathrm{DARit}+\beta 2 \mathrm{D} 1+\beta 3 \mathrm{D} 2+\beta 4(\mathrm{D} 1 \times \mathrm{DARit})+\beta 5(\mathrm{D} 2 \times \mathrm{DARit})+\beta 6 \mathrm{SIZEit}+\beta 7 \mathrm{LEVit} \\
& +\beta 8 \text { GROWTHit }+ \text { iit } \\
& \mathrm{Qit}=\beta 0+\beta 1 \mathrm{DAPit}+\beta 2 \mathrm{D} 1+\beta 3 \mathrm{D} 2+\beta 4(\mathrm{D} 1 \times \mathrm{DAPit})+\beta 5(\mathrm{D} 2 \times \mathrm{DAPit})+\beta 6 \mathrm{SIZEit}+\beta 7 \mathrm{LEVit} \\
& +\beta 8 \text { GROWTHit }+ \text { sit } \\
& \text { Qit }=\beta 0+\beta 1 \text { DIit }+\beta 2 \text { D } 1+\beta 3 \text { D2 }+\beta 4(\text { D } 1 \times \text { DIit })+\beta 5(\text { D } 2 \times \text { DIit })+\beta 6 \text { SIZEit } \\
& +\beta 7 \text { LEVit }+\beta 8 \text { GROWTHit }+\varepsilon i t
\end{aligned}
$$

\section{RESULTS}

\section{Data Analysis}

Descriptive statistics: To determine the general characteristics of the variables, as well as estimation of model and detailed analysis, familiarity with descriptive statistics of variables is required. Descriptive statistics calculate 
Table 2. Descriptive statistics variables

\begin{tabular}{ccccccc}
\hline Variable & Mean & Median & Max & Min & Standard deviation & Observation \\
\hline $\mathrm{Q}$ & 1.5930 & 1.3216 & 11.7900 & 0.2100 & 0.6099 & 960 \\
\hline $\mathrm{D} 1$ & 0.3329 & 0.0000 & 1.0000 & 0.0000 & 0.4442 & 960 \\
\hline $\mathrm{D} 2$ & 0.6659 & 0.0000 & 2.0000 & 0.0000 & 0.8884 & 960 \\
\hline $\mathrm{CCC}$ & 260.6705 & 222.2975 & 8772.99 & -51.4900 & 136.7946 & 960 \\
\hline $\mathrm{DAR}$ & 117.0273 & 86.1394 & 3626.65 & 0.0200 & 81.5389 & 960 \\
\hline DAP & 51.1631 & 35.9230 & 1565.25 & 0.0300 & 98.0472 & 960 \\
\hline DI & 194.8063 & 158.8904 & 8899.89 & 0.2600 & 38.0826 & 960 \\
\hline LEV & 0.6540 & 0.6595 & 2.1200 & 0.0000 & 0.1343 & 960 \\
\hline SIZE & 12.7351 & 12.6724 & 16.6700 & 0.0000 & 0.9695 & 960 \\
\hline GROWTH & 0.0144 & 0.0049 & 0.7100 & 0.0000 & 0.0158 & 960 \\
\hline
\end{tabular}

Table 3. Correlation Matrix of Variables

\begin{tabular}{|c|c|c|c|c|c|c|c|c|c|c|c|}
\hline & & $\mathbf{Q}$ & CCC & DAR & DAP & DI & D1 & D2 & SIZE & LEV & GROWTH \\
\hline \multirow{3}{*}{ Q } & Pearson Correlation & 1 & - & - & - & - & - & - & - & - & - \\
\hline & Sig. (2-tailed) & & - & - & - & - & - & - & - & - & - \\
\hline & $\mathrm{N}$ & 960 & - & - & - & - & - & - & - & - & - \\
\hline \multirow{3}{*}{ CCC } & Pearson Correlation & -0.011 & 1 & - & - & - & - & - & - & - & - \\
\hline & Sig. (2-tailed) & 0.731 & & - & - & - & - & - & - & - & - \\
\hline & $\mathrm{N}$ & 960 & 960 & - & - & - & - & - & - & - & - \\
\hline \multirow{3}{*}{ DAR } & Pearson Correlation & $-0.097^{* *}$ & $0.428^{* *}$ & 1 & - & - & - & - & - & - & - \\
\hline & Sig. (2-tailed) & 0.003 & 0.000 & & - & - & - & - & - & - & - \\
\hline & $\mathrm{N}$ & 960 & 960 & 960 & - & - & - & - & - & - & - \\
\hline \multirow{3}{*}{ DAP } & Pearson Correlation & -0.024 & $-0.705^{* *}$ & 0.018 & 1 & - & - & - & - & - & - \\
\hline & Sig. (2-tailed) & 0.451 & 0.000 & 0.585 & & - & - & - & - & - & - \\
\hline & $\mathrm{N}$ & 960 & 960 & 960 & 960 & - & - & - & - & - & - \\
\hline \multirow{3}{*}{ DI } & Pearson Correlation & 0.015 & $0.516^{* *}$ & $0.087^{* *}$ & $0.103^{* *}$ & 1 & - & - & - & - & - \\
\hline & Sig. (2-tailed) & 0.648 & 0.000 & 0.007 & 0.001 & & - & - & - & - & - \\
\hline & $\mathrm{N}$ & 960 & 960 & 960 & 960 & 960 & - & - & - & - & - \\
\hline \multirow{3}{*}{ D1 } & Pearson Correlation & -0.002 & 0.035 & 0.017 & -0.011 & 0.036 & 1 & - & - & - & - \\
\hline & Sig. (2-tailed) & 0.959 & 0.276 & 0.609 & 0.738 & 0.260 & & - & - & - & - \\
\hline & $\mathrm{N}$ & 958 & 958 & 958 & 958 & 958 & 958 & - & - & - & - \\
\hline \multirow{3}{*}{ D2 } & Pearson Correlation & -0.027 & -0.040 & -0.001 & 0.047 & -0.006 & $-0.499^{* *}$ & 1 & - & - & - \\
\hline & Sig. (2-tailed) & 0.408 & 0.213 & 0.973 & 0.142 & 0.856 & 0.000 & - & - & - & - \\
\hline & $\mathrm{N}$ & 958 & 958 & 958 & 958 & 958 & 958 & 958 & - & - & - \\
\hline \multirow{3}{*}{ SIZE } & Pearson Correlation & $-0.109^{* *}$ & $-0.171^{* *}$ & $-0.192^{* *}$ & 0.039 & $-0.117^{* *}$ & $0.146^{* *}$ & -0.063 & 1 & - & - \\
\hline & Sig. (2-tailed) & 0.001 & 0.000 & 0.000 & 0.233 & 0.000 & 0.000 & 0.053 & & - & - \\
\hline & $\mathrm{N}$ & 960 & 960 & 960 & 960 & 960 & 958 & 958 & 960 & - & - \\
\hline \multirow{3}{*}{ LEV } & Pearson Correlation & 0.017 & 0.004 & 0.061 & 0.019 & -0.009 & -0.045 & -0.010 & $0.091^{* *}$ & 1 & -- \\
\hline & Sig. (2-tailed) & 0.598 & 0.897 & 0.060 & 0.555 & .786 & 0.163 & 0.760 & 0.005 & - & - \\
\hline & $\mathrm{N}$ & 960 & 960 & 960 & 960 & 960 & 958 & 958 & 960 & 960 & - \\
\hline \multirow{3}{*}{ GROWTH } & Pearson Correlation & 0.026 & 0.011 & -0.004 & 0.045 & $0.084^{* *}$ & -0.033 & -0.024 & $-0.104^{* *}$ & 0.008 & 1 \\
\hline & Sig. (2-tailed) & 0.414 & 0.730 & 0.902 & 0.165 & 0.009 & 0.305 & 0.456 & 0.001 & 0.795 & \\
\hline & $\mathrm{N}$ & 960 & 960 & 960 & 960 & 960 & 958 & 958 & 960 & 960 & 960 \\
\hline
\end{tabular}

${ }^{*}$ Correlation is significant at the 0.05 level (2-tailed).

${ }^{* *}$ Correlation is significant at the 0.01 level (2-tailed)

the parameters of population and including central indexes and population dispersion and so on. Table 2 shows descriptive Statistics variables including mean, median, maximum, minimum, and standard deviation, etc. For example, for variable performance (TQ) mean, median, maximum and minimum equal with 1.59, 1.32, 11.79, and 0.21 , respectively.

The correlation matrix of variables: Table 3 indicates the correlation between variables in level sig $\leq 0.01$ and sig $\leq 0.05$. For example, the correlation coefficient of performance variable (TQ) and collection period (DAR) is -0.097 which is significant at the level of 0.05 .

Before testing the hypothesis based on the results, we must ensure the accuracy of the results. For this aim, Ftest was used to determine the significance of the model. Probability of calculated F statistics for all of four models is equal to (0.0000) and it can be claimed that the fitted regression model is significant. According to the determination coefficient of fitted model, model (1) is equal to 0.0541 and model (2) is equal to 0.0595; model (3) is equal to 0.0483 and model (4) is equal to 0.0488, It can be argued that what percentage of changes in the dependent variable (performance), is explained by the independent variables. Durbin-Watson statistic values for all four models were in the range of 1.5 to 2.5 and show that there is no correlation between the errors. The results of heteroscedasticity of variance test show that in all the research models there is a problem of heteroscedasticity of variance (Because all probability, or calculated p-value are less than 0.05 ). So the final estimation of these models 
Dutch Journal of Finance and Management, 3(1), em0057

Table 4. Statistical results of models 1 to 4

\begin{tabular}{|c|c|c|c|c|c|c|c|c|}
\hline \multirow{2}{*}{$\begin{array}{c}\text { Model } \\
\text { Variable }\end{array}$} & \multicolumn{2}{|l|}{1} & \multicolumn{2}{|c|}{2} & \multicolumn{2}{|l|}{3} & \multicolumn{2}{|l|}{4} \\
\hline & Coefficient & Probe & Coefficient & Probe & Coefficient & Probe & Coefficient & Probe \\
\hline $\mathrm{C}$ & 3.1682 & 0.0000 & 2.2365 & 0.0000 & 2.0892 & 0.0000 & 2.1129 & 0.0000 \\
\hline CCC & -9.7400 & 0.0146 & $\begin{array}{ll}---- \\
\end{array}$ & $\begin{array}{ll}---- \\
\end{array}$ & $\begin{array}{ll}---- \\
--\end{array}$ & $\begin{array}{ll}---- \\
\end{array}$ & $\begin{array}{ll}---- \\
\end{array}$ & $\begin{array}{ll}---- \\
\end{array}$ \\
\hline DAR & ----- & ----- & -0.0002 & 0.0030 & ----- & $\begin{array}{ll}---- \\
\end{array}$ & ----- & ----- \\
\hline DAP & $\begin{array}{ll}---- \\
\end{array}$ & $\begin{array}{ll}---- \\
\end{array}$ & $\begin{array}{ll}---- \\
\end{array}$ & $\begin{array}{ll}---- \\
-1\end{array}$ & -0.0001 & 0.7207 & $\begin{array}{ll}---- \\
\end{array}$ & $\begin{array}{ll}---- \\
\end{array}$ \\
\hline DI & $\begin{array}{ll}----- \\
\end{array}$ & $\begin{array}{l}---- \\
\end{array}$ & ----- & $\begin{array}{ll}----- \\
\end{array}$ & $\begin{array}{ll}----- \\
\end{array}$ & $\begin{array}{ll}----- \\
\end{array}$ & -6.8800 & 0.1601 \\
\hline SIZE & -0.0730 & 0.0005 & -0.0788 & 0.0000 & -0.0680 & 0.0000 & -0.0688 & 0.0000 \\
\hline $\mathrm{LEV}$ & 0.3006 & 0.0000 & 0.3232 & 0.0002 & 0.2964 & 0.0007 & 0.2887 & 0.0009 \\
\hline GROWTH & 0.5405 & 0.1244 & 0.4887 & 0.1508 & 0.5502 & 0.1128 & 0.5769 & 0.1013 \\
\hline \multirow{2}{*}{$\mathrm{F}$} & \multirow{2}{*}{\multicolumn{2}{|c|}{$\begin{array}{l}13.6690 \\
(0.0000)\end{array}$}} & \multirow{2}{*}{\multicolumn{2}{|c|}{$\begin{array}{l}15.1045 \\
(0.0000)\end{array}$}} & \multirow{2}{*}{\multicolumn{2}{|c|}{$\begin{array}{l}12.1394 \\
(0.0000)\end{array}$}} & \multirow{2}{*}{\multicolumn{2}{|c|}{$\begin{array}{l}12.2594 \\
(0.0000)\end{array}$}} \\
\hline & & & & & & & & \\
\hline $\mathrm{R} 2$ & \multicolumn{2}{|c|}{0.0541} & \multicolumn{2}{|c|}{0.595} & \multicolumn{2}{|c|}{0.0483} & \multicolumn{2}{|c|}{0.0488} \\
\hline DW & \multicolumn{2}{|c|}{1.7541} & \multicolumn{2}{|c|}{1.7500} & \multicolumn{2}{|c|}{1.7397} & \multicolumn{2}{|c|}{1.7489} \\
\hline Heteroscedasticity & \multicolumn{2}{|c|}{0.0000} & \multicolumn{2}{|c|}{0.0000} & \multicolumn{2}{|c|}{0.0000} & \multicolumn{2}{|c|}{0.0000} \\
\hline Housman & \multicolumn{2}{|c|}{0.0002} & \multicolumn{2}{|c|}{0.0001} & \multicolumn{2}{|c|}{0.0001} & \multicolumn{2}{|c|}{0.0002} \\
\hline
\end{tabular}

is done using GLS test. Hausman test results show that for all models fixed effects method should be used. The estimated coefficient CCC for the independent variable in Table 4 indicates that there is a significant negative relationship between the cash conversion cycle and performance when error level is 0.05 . Because, estimated pvalue for this independent variable coefficient is less than 0.05 . The estimated coefficient of independent variable DAR in Table 4 shows that there is a negative and significant relationship between debt collection period and performance at error level of 0.05 . The reason is that the estimated $\mathrm{p}$-value for this independent variable coefficient is less than 0.05. The estimated coefficient of independent variable DAP in Table 4 indicates that there is no significant relationship between payment period and performance at error level of 0.05 . The reason is that the estimated $\mathrm{p}$-value for coefficient of this independent variable is greater than 0.05 . The estimated coefficient for the independent variable DI in Table 4 indicates the lack of a significant relationship between the level of inventory turnover and performance at error level of 0.05 . The reason is that the estimated $\mathrm{p}$-value for coefficient of this independent variable is greater than 0.05 . With this description, we conclude that the first and second hypothesis is confirmed.

Before testing the hypothesis based on the results, we must ensure the accuracy of the results. For this aim, Ftest was used to determine the significance of the model. Probability of calculated F statistics for all of four models is equal to (0.0000) and it can be claimed that the fitted regression model is significant. According to the determination coefficient of fitted model, model (5) is equal to 0.6751, and model (6) is equal to 0.6677; model (7) is equal to 0.6782 and model (8) is equal to 0.6765 , it can be argued that what percentage of changes in the dependent variable (performance), is explained by the independent variables. Durbin-Watson statistic values for all four models were in the range of 1.5 to 2.5 and show that there is no correlation between the errors. The results of heteroscedasticity of variance test show that in all the research models there is a problem of heteroscedasticity of variance (Because all probability, or calculated p-value are less than 0.05 ). So the final estimation of these models is done using GLS test. Hausman test results show that for all models should be used of fixed effects method. The estimated coefficient $\mathrm{D}_{1} * \mathrm{CCC}, \mathrm{D}_{1} * \mathrm{DAR}, \mathrm{D}_{2} * \mathrm{CCC}, \mathrm{D}_{2} * \mathrm{DAR}, \mathrm{D}_{1} * \mathrm{DAP}, \mathrm{D}_{2} * \mathrm{DAP}, \mathrm{D}_{1} * \mathrm{DI}, \mathrm{D}_{2} * \mathrm{DI}$ for the independent variable in Table 5 shows that there is no significant relationship between the interactive effect of the cash conversion cycle, the period of collection of receivables, payment of obligations, inventory turnover period, recession period and boom period with performance at error level of 0.05 . The reason is that the estimated $\mathrm{p}$-value for coefficient of this independent variable of research is greater than 0.05 . With this description, we conclude that the fifth to eighth hypothesis is rejected. 
Table 5. Statistical Results of model 5 to 8

\begin{tabular}{|c|c|c|c|c|c|c|c|c|}
\hline \multirow{2}{*}{$\begin{array}{c}\text { Model } \\
\text { Variable }\end{array}$} & \multicolumn{2}{|c|}{5} & \multicolumn{2}{|c|}{6} & \multicolumn{2}{|c|}{7} & \multicolumn{2}{|c|}{8} \\
\hline & Coefficient & Probe & Coefficient & Probe & Coefficient & Probe & Coefficient & Probe \\
\hline $\mathrm{C}$ & 1562.283 & 0.0000 & 1791.42 & 0.0000 & 1.6033 & 0.0000 & 1731.80 & 0.0000 \\
\hline $\mathrm{D}_{1}$ & 84.9582 & 0.0017 & 84.1177 & 0.0004 & 0.0301 & 0.2500 & 62.3983 & 0.0272 \\
\hline $\mathrm{D}_{2}$ & 2.8575 & 0.8446 & 18.9340 & 0.2164 & 0.0080 & 0.5304 & 14.9889 & 0.2990 \\
\hline $\mathrm{CCC}$ & 0.0427 & 0.5462 & $\begin{array}{l}---- \\
-4\end{array}$ & $\begin{array}{ll}---- \\
\end{array}$ & $\begin{array}{ll}---- \\
\end{array}$ & $\begin{array}{l}---- \\
\end{array}$ & $\begin{array}{ll}---- \\
\end{array}$ & $\begin{array}{ll}---- \\
\end{array}$ \\
\hline $\mathrm{D}_{1} * \mathrm{CCC}$ & -0.0841 & 0.3208 & ----- & $\begin{array}{l}---- \\
\end{array}$ & $\begin{array}{l}---- \\
\end{array}$ & $\begin{array}{l}---- \\
\end{array}$ & $\begin{array}{l}---- \\
\end{array}$ & ----- \\
\hline $\mathrm{D}_{2} * \mathrm{CCC}$ & 0.0128 & 0.7609 & ----- & ----- & ----- & ----- & ----- & ----- \\
\hline DAR & ----- & $\begin{array}{l}---- \\
\end{array}$ & -0.0602 & 0.6444 & $\begin{array}{l}---- \\
\end{array}$ & ----- & $\begin{array}{l}---- \\
\end{array}$ & ----- \\
\hline $\mathrm{D}_{1} * \mathrm{DAR}$ & ----- & ----- & -0.1368 & 0.3297 & ------ & ----- & $\begin{array}{ll}----- \\
\end{array}$ & ----- \\
\hline $\mathrm{D}_{2} * \mathrm{DAR}$ & ----- & ----- & -0.1140 & 0.2359 & ----- & ----- & $\begin{array}{ll}---- \\
\end{array}$ & ----- \\
\hline DAP & $\begin{array}{ll}---- \\
\end{array}$ & ----- & ------ & ------ & -0.0002 & 0.5455 & ----- & ----- \\
\hline $\mathrm{D}_{1} * \mathrm{DAP}$ & ------ & ----- & ------ & ----- & 0.0005 & 0.1207 & $\begin{array}{ll}---- \\
\end{array}$ & ----- \\
\hline $\mathrm{D}_{2} * \mathrm{DAP}$ & $\begin{array}{ll}---- \\
\end{array}$ & $\begin{array}{ll}---- \\
\end{array}$ & $\begin{array}{ll}---- \\
\end{array}$ & $\begin{array}{ll}---- \\
\end{array}$ & 0.0000 & 0.7751 & $\begin{array}{ll}---- \\
-1\end{array}$ & ----- \\
\hline DI & ----- & $\begin{array}{ll}----- \\
\end{array}$ & $\begin{array}{ll}---- \\
\end{array}$ & $\begin{array}{ll}---- \\
\end{array}$ & $\begin{array}{ll}----- \\
\end{array}$ & $\begin{array}{ll}----- \\
\end{array}$ & 0.0729 & 0.4169 \\
\hline $\mathrm{D}_{1} * \mathrm{DI}$ & ----- & ----- & ----- & ----- & ----- & ----- & 0.0245 & 0.8441 \\
\hline $\mathrm{D}_{2} * \mathrm{DI}$ & $\begin{array}{ll}----- \\
\end{array}$ & $\begin{array}{ll}----- \\
\end{array}$ & $\begin{array}{ll}---- \\
\end{array}$ & $\begin{array}{ll}---- \\
\end{array}$ & $\begin{array}{ll}----- \\
\end{array}$ & $\begin{array}{ll}----- \\
\end{array}$ & -0.0541 & 0.3504 \\
\hline SIZE & -43.9262 & 0.0890 & -59.8503 & 0.0313 & -0.0453 & 0.0616 & -57.9183 & 0.0197 \\
\hline $\mathrm{LEV}$ & 782.6507 & 0.0000 & 773.1536 & 0.0000 & 0.7830 & 0.0000 & 796.9487 & 0.0000 \\
\hline GROW'TH & 156.4651 & 0.6211 & 159.456 & 0.6122 & 0.0661 & 0.8396 & 121.2623 & 0.7225 \\
\hline $\mathrm{F}$ & \multicolumn{2}{|c|}{$\begin{array}{l}18.6348 \\
(0.0000)\end{array}$} & \multicolumn{2}{|c|}{$\begin{array}{l}18.0190 \\
(0.0000)\end{array}$} & \multicolumn{2}{|c|}{$\begin{array}{l}18.9003 \\
(0.0000)\end{array}$} & \multicolumn{2}{|c|}{$\begin{array}{l}18.7512 \\
(0.0000)\end{array}$} \\
\hline $\mathrm{R}^{2}$ & \multicolumn{2}{|c|}{0.6751} & \multicolumn{2}{|c|}{0.6677} & \multicolumn{2}{|c|}{0.6782} & \multicolumn{2}{|c|}{0.6765} \\
\hline DW & \multicolumn{2}{|c|}{1.8090} & \multicolumn{2}{|c|}{1.7932} & \multicolumn{2}{|c|}{1.8082} & \multicolumn{2}{|c|}{1.7994} \\
\hline Heteroscedasticity & \multicolumn{2}{|c|}{0.0006} & \multicolumn{2}{|c|}{0.0009} & \multicolumn{2}{|c|}{0.0009} & \multicolumn{2}{|c|}{0.0005} \\
\hline Hausman & \multicolumn{2}{|c|}{0.0000} & \multicolumn{2}{|c|}{0.0000} & \multicolumn{2}{|c|}{0.0000} & \multicolumn{2}{|c|}{0.0000} \\
\hline
\end{tabular}

\section{DISCUSSION AND CONCLUSION}

The aim of this study was to investigate the relationship between working capital management and performance of companies in different business cycles. Working capital management is one of the key areas of financial management and managing organizations because it directly affects the liquidity and profitability of the company. The possibility of bankruptcy for companies exposed to improper management of working capital even when profitability is positive. Working capital management, including planning and control of current assets and liabilities is such a way that can mitigates the risk of failing to meet short-term commitments on the one hand and on the other hand it avoids excessive investment in these assets. In this study, the relationship between the components of working capital management and performance of companies in different business cycles has been studied. Components intended for working capital management are: days account receivable, days inventory, days account payable. According to theoretical foundations, reducing the cash conversion cycle is a desirable state that Companies are looking for. According to the results it can be said that there is a significant negative relationship between cash conversion cycle and firm performance. Cash conversion cycle represents a period of time that the company's operating cash spent to produce a product item. And managers can reduce cash conversion cycle as much as possible, creating a positive value and profitability for their shareholders and this requires good liquidity planning and proper management of receivables and payables and the proper exploitation of investment opportunities and financing. According to the results it can be said that there is a significant negative relationship between collection period and firm's performance. Days account receivable is considered as a measure to estimate the amount of time required to collect cash proceeds of the sales. Managers can with reduction as much as possible of the collection period create a positive value and profitability for their shareholders and this will be achieved with good management of accounts receivable and effective administration of proceeds.

\section{REFERENCES}

Aregbeyen, O. (2011). The effects of working capital management on the profitability of Nigerian manufacturing firms. Journal of Business Economics and Management, 14(3), 520-534. https://doi.org/10.3846/16111699.2011.651626

Baharmoghadam, M., Mohammad Reza Khani, V. and Hoshmand Zaferaniyeh, R. (2012). The effect of specific features on working capital management. Journal of financial Accounting Empirical Research, 2(4), 71-89.

Braun, M. and Larrain, B. (2005). Finance and the business cycle: international, inter-industry evidence. Journal of Finance, 60(3), 1097-1128. https://doi.org/10.1111/j.1540-6261.2005.00757.x 
Chiou, J., Cheng, L. and Wu, H. (2006). The determinants of working capital management. Journal of Am. Acad. Business (Cambridge), 10(1), 149-155.

Einarsson, T. and Marquis, M. (2001). Bank intermediation over the business cycle. Journal of Money Credit Banking, 33(4), 876-899. https://doi.org/10.2307/2673927

Gill, A., Biger, N. and Mathur, N. (2010). The Relation between Working Capital management And Profitability: Evidence from the United States. Journal of Business and Economics Jurnal, 10, 1-9.

Graham, M., Enqvist, J. and Nikkinen, J. (2014). The impact of Working Capital Management on firm profitability in different business cycles: Evidence from Finland. Journal of Research in International Business and Finance, 31, 116. https://doi.org/10.1016/j.ribaf.2014.03.005

Karadagli, E. (2012). The Effect of Working Capital Management on the Profitability of Turkish SMEs. Journal of Economics. Finance and Management Sciences, 36(2).

Korajczyk, R. and Levy, A. (2003). Capital structure choice: macroeconomic conditions and financial constraints. J. Financial Economics, 68(1), 75-109. https://doi.org/10.1016/S0304-405X(02)00249-0

Lazaridis, I. and Tryfonidis, D. (2006). Relationship between working capital management and profitability of listed companies on the Athens Stock Exchange. Journal of Financial Management Anal, 19(1), 26-35.

Lotfi, M., Dianati Deylami, Z. and Azadbakhsh, K. (2012). The impact of working capital management is based on the cash conversion cycle (Gytman) on reducing the risk of fall (loss) stock price. Journal of Accounting and Auditing Management, 1(4), 55-64.

Mohammadi, M. (2009). The impact of working capital management on profitability society listed companies in Tehran Stock Exchange. Journal of Management, 6(14), 80-91.

Samadi Largany, M. and Aymani, M. (2013). The relationship between working capital management and cash holdings in listed companies in Tehran Stock Exchange. Journal of Accounting and Auditing Management, 2(5), 3951.

Wang, Y. (2002). Liquidity management, operating performance and corporate value: evidence from Japan and Taiwan. Journal of Multinational Financial Manage, 12(2), 159-169. https://doi.org/10.1016/S1042444X(01)00047-0

Yeboah, B. and Kwaku Agyei, S. (2012). Working Capital Management and Cash Holdings of Banks in Ghana. European Journal of Business and Management, 4(13). 